\title{
THREE GENERATIONS OF WOMEN: LEARNING AND SCHOOLING AMONGST THE ADNYAMATHANHA
}

\author{
Aspects of the Lives of Pearl McKenzie, \\ Pauline Coulthard, and Charlene Coulthard ${ }^{1}$
}

\section{Gillian Weiss}

This paper arises from the stories of three Adnyamathanha women of the Flinders Ranges in South Australia. They are three generations of a single family, mother, daughter, and granddaughter. The stories do not represent their whole lives but only limited aspects, particularly in relation to their childhoods, their culture(s) and some of the ways they acquired their knowledge(s), and the ways in which they strive to use, retain, and preserve them in their daily living and perceived futures. Their stories were told to me, in their own words, in a series of taped interviews. As such, they represent a portion of each woman's recall and remembering of parts of her own life as well as parts of the lives of the other two, for all three have lived and interacted together and for each to separate herself out from the others as a totally isolated entity is impossible. Each exists in a

1. This project is a part of a larger collaborative study by the Art Education Research Group of the University of South Australia, and the University of British Columbia, being done with the Adnyamathanha people in South Australia, the Sechelt people in British Columbia, and the Wikwemikong people in Manitoulin Island, Ontario, in a continuing project entitled 'A comparative study of the effects of colonisation on the art of selected groups of Australian and Canadian Aboriginal peoples.' Tony Rogers of the University of South Australia was involved with some of the interviewing and was of great assistance and support when it came to the writing of this paper. My thanks also to Bob Petersen, Craig Campbell, Margaret Peters, Keren Wicks, Kay Whitehead, Leah Simons, and Dot Hudson for valuable discussion and criticism in Australia. Since the paper was presented at the 1993 ANZHES Conference I have had the opportunity to spend seven months in British Columbia, working with the Sechelt people and colleagues at the University of British Columbia. Many of the methodological problems which I have raised in this paper are already a part of academic discussion in Canada and the USA; others have yet to be addressed. It seems best at this stage to leave the North American context untouched in this paper. My thanks, though, to colleagues at UBC, in particular, Jean Barman, Tim Stanley, Peter Seixas, Neil Sutherland, and J. Donald Wilson for stimulating and helpful discussion. 
myriad of relationships either in past or present reality, or in future possibility; each is mother, wife, daughter, granddaughter, and sister.

These stories and the implications we can draw from them in one sense stand alone. I want to discuss this point more fully later. But they also are intimately connected with the broader experience of the Adnyamathanha as a people and less directly, but still importantly, with Australian Aboriginal history generally. Because of the total dominance of white culture since colonization there has been no recognition of the existence of Aboriginal history; in the white academic sense of the term there has been no Aboriginal history until recently. And given the dominance of the eastern states in white Australian culture, the history of Aboriginal peoples in South Australia is even more poorly documented. This article therefore will assume ignorance on the part of both Australian and Canadian readers and gives a brief overview of the Adnyamathanha experience since white settlement, in order to set the context for the stories of the three women.

When the colony of South Australia and Adelaide, its capital, were established, the fertile lands around it were rapidly developed. The local Aboriginal people, the Kaurna, disappeared almost completely within twenty years. Settlers then moved out further looking for suitable agricultural lands. Clearing the land for agriculture had an immediate effect on Aboriginal people, removing their traditional food supplies. Whites, moreover, considered the presence of Aboriginals as incompatible with agriculture. Little is known of what happened to Aboriginal groups who lived in the agricultural areas but few survived the intrusion of whites into their lands. ${ }^{2}$

The impact of pastoralism on Aboriginal people in the drier lands further inland was not as immediately devastating as urbanization and agriculture were to those closer to Adelaide. Pastoral leases allowed for their free movement through the land and the natural environment was not destroyed straight away. However, there were long term effects as pastoralists controlled the water sources and stock ate many of the plants traditionally used as food by both Aboriginal people and native animals. ${ }^{3}$ The Aboriginal people in some pastoral areas were virtually wiped out over time, others survived with minimal impact on their traditional lifestyle, yet other groups adapted to the changed circumstances and survived. The Adnyamathanha of the Northern Flinders Ranges were one of the surviving groups.

The first Adnyamathanha contact with whites was in the 1840 s as explorers pushed northwards, followed a decade later by the early pastoralists. The Adnyamathanha, like some other Aboriginal groups rapidly adjusted their hunting techniques to the new conditions and began to replace their native game with

2. Peggy Brock, Yura and Udnyu: A History of the Adnyamathanha of the North Flinders Ranges (Adelaide: Wakefield Press, 1985), 10.

3. Ibid., 11. 
sheep and cattle. ${ }^{4}$ Some violent clashes ensued as well as the inevitable epidemics of white diseases but by the 1860s the situation had calmed down and two decades later those Adnyamathanha who survived had adapted to the pastoral economy. 5

The Adnyamathanha now co-existed with the white settlers, their values, and their economy, though as Brock notes, 'at great loss to their health and the survival of individual members of their community' due to the poor nutritional quality of the government rations and increasingly sparse traditional food available. ${ }^{6}$ Some attempts were made to send children of mixed race to mission stations or residential schools but the Adnyamathanha managed to avoid this action which was so devastating for some other Aboriginal groups. ${ }^{7}$ Station work was a major source of employment, though usually sporadic. Along with hunting dingoes and rabbits, for which they were paid by the scalp, and euros and kangaroos for their skins, and occasional employment in local mines or at the Mount Serle Camel Depot, most families were able to survive in good times even if they had to rely on government rations when the seasons were poor. In times of drought they were particularly vulnerable as they no longer had access to traditional water holes and, of course, traditional foods became scarce. ${ }^{8}$

By the end of the 1920s it was becoming increasingly difficult for the Adnyamathanha to move from camp to camp in the traditional manner. Many station owners were unwilling to have them camp on their property and those who managed to find work on stations had their mobility restricted by their employment. Missionaries from the non-denominational United Aborigines Mission had begun their work eight years earlier at Ram Paddock Gate, a traditional Adnyamathanha camp ground, but the station owner was increasingly unwilling to have the people stay there. In 1930 Nepabunna settlement was established about 190 kilometres north of Hawker after prolonged negotiation by the missionaries with the owner of Balcanoona Station for some land. ${ }^{9}$ This was not a traditional camping area as the ground was rather rocky, but wells blasted in the creekbed ensured a permanent water supply. The Adnyamathanha were

4. Henry Reynolds, The Other Side of the Frontier: Black Response to White Dominance, 1788-1980 (Sydney: Allen and Unwin, 1982), 38, 39.

5. Brock, Yura and Udnyu, chap. 2.

6. Ibid., 34.

7. For instance, see Tony Austin, "Mainly a Question of Environment": The Kahlin Home for Aboriginal Children of Mixed Descent 1911-1927,' History of Education Review 21, 1 (1992); for the Aboriginal perspective see Barbara Cummings, Take this child... FromKahlin Compound to the Retta Dixon Children's Home (Aboriginal Studies Press, 1990).

8. Brock, Yura and Udnyu, 39.

9. A.E. Gerard, History of the United Aborigines Mission (UAM, n.d., Mortlock Library), 21, 22. 
not particularly happy with the location initially but today it is very important to them and they consider it home.

Peggy Brock claims in her brief history of the Adnyamathanha that

it [Nepabunna] is central to their traditional lands and a place of refuge from the white world. The retention of a 'home' has enabled the Adnyamathanha to retain a cultural and linguistic identity which they might have otherwise lost. ${ }^{10}$

While there is no doubt that Nepabunna has played an important role in the lives of the Adnyamathanha as a people, as well as individuals, there are other factors which are also important in the overall survival and strength of the Adnyamathanha culture. Some aspects of these factors are apparent in the lives of the three women recounted here. Only one of them has ever lived at Nepabunna and she for only a few years immediately after it was founded. Taken together, the lives of these women span the time period from just prior to the arrival of the first missionaries to the present day. However, the significance of their experiences is far broader than this. Through Pearl McKenzie, the eldest, they have direct contact with the Adnyamathanha of the late nineteenth century-those individuals who were the first generation to co-exist with whites, to adapt their traditional ways to the changed physical, economic, and social conditions that existed after half a century of colonial invasion. Pearl's childhood was lived in as traditional a manner as was still then possible and the influence of tribal ways is still very strong in her. Through Charlene Coulthard, her granddaughter, the link will extend into the twenty-first century as she has children and passes on to them their Adnyamathanha heritage. Pauline Coulthard, Pearl's daughter and Charlene's mother, is the link between them.

\section{Pearl}

Pearl McKenzie was born sometime in 1922 at Burr Well Station, the daughter of Henry and May Wilton. She was the second of nine children, three boys and six girls. The children were all born in the traditional manner in a creek bed.

...out in the open. Yes, the creek down some way. And then I remember Mum having another baby at Ram Paddock, and out from the house in

10. Brock, Yura and Udnyu, 13. 
the creek. Only the womenfolks would be there, and even the father wasn't allowed to look at the baby until it's a week old. [1:27] ${ }^{11}$

Traditional ways of childbirth were still important to many Adnyamathanha women at this time but for many women, even years later, there was little alternative. Pearl's youngest brother, born in 1945 after she had married and moved away, was also born in the creek bed, for there were no medical facilities nearby. Skills at childbirth were an integral part of Adnyamathanha women's culture but all Pearl's five children, from the first in 1947, would be born at the Hawker hospital, because at Martin's Well where she and her husband were living there were no Adnyamathanha women to assist. Pearl had great respect for and confidence in the traditional midwives but nevertheless she chose to make the 93 km. journey from Martin's Well to Hawker for all the births.

My mother was a really good midwife, you know, and some others, you know. But I rather came down here I thought. [3:6]

As Pearl grew up her life continued to be very close in many ways to a traditional one, despite the increasing influence of Udnyu (white) ways. ${ }^{12}$ While the family never moved outside of their traditional lands, within them they moved around frequently, depending on jobs that her father could get and where other relations were living.

We was, you know, going around from station to station. My Dad used to do a bit of anything, or a few crutching and so forth. We all landed back at Ram Paddock Gate, and that's why we....I don't remember going there but I remember growing up there....Then we moved on to Nepabunna. We was there a long time. [1:21]

Food gathering occupied Pearl and the other young girls for quite long periods.

11. Each excerpt from a taped interview is identified as follows: the first number represents the first, second, or third interview with each individual. The number or numbers following the colon are the page numbers of the typed transcript of each interview. Interviews taped on the following dates are used for this paper: Pearl McKenzie: 1. 21.2.93; 2. 8.2.93; 3. 21.5.93; Pauline Coulthard: 1. 7.2.93; 2. 21.5.93; Charlene Coulthard: 1 . 6.2.93; 2. 20.5 .93

12. In the Adnyamathanha language Udnyu literally means 'corpse.' At first contact whites were believed to be walking corpses because of their pale skins. 
So most of the time we used to just roam around, you know, setting rabbit traps or picking wild peaches, wild pears, and that, you know. [1:21]

Boys largely worked and played separately. Pearl does not remember food gathering as being a job that was required of her; it was simply a part of life. And even if it was expected, the enjoyment that it generated is the strongest part of the memory, and that pleasure remains with her today. Work and pleasure were frequently very closely tied together.

...they used to have two buckets. You know, two, on each side of the windlass we used to put them. One'd go down and one bucket will come up with water. And there used to be a landing trough if we wanted to water our donkeys. And they watered the donkeys. One bucket would be down, you see. When you put the other one down, the other comes up. Oh, it was really fun. [3:7]

Ceremonial activities also combined enjoyment with their more serious cultural and spiritual elements.

The first stage [of initiation for boys], you know, it was really fun for everyone. It more or less like a sports day for us girls, too, doing little odd jobs and, you know. The part that we used to take part used to be a big camp. Everyone used to move out from the main camp to a certain area around, you know. Stay there all day and a night and until next morning when they finished and we all moved back to our usual camp.

The ongoing group activities were learning situations. Like her peers, Pearl would watch until she was ready to try for herself. Some skills, like weaving rugs from strips of kangaroo hide, she never felt the need to try for herself; others, like carving emu eggs, she utilized years after.

At Nepabunna. We used to play around and this old chap, he used to sit around, you know, doing emu egg. And he used to put a bucking horse or a eagle or something like that, yes. But I never take to it then until [pause] in '46...Because I had nothing to do, no children. Because my husband used to go out track riding all day and I thought I'd do something, so I made these emu egg — you know, carved it out. [1:5,6]

Domestic skills were learned by watching and Pearl used the same method to pass her skills on to her daughter, Pauline, and granddaughters. 
I think she just picked it up. To see what I'm doing, same as I did. But they can all cook. Pauline really, you know, make anything, and so's the two daughters [Pearl's granddaughters, Charlene and Carey]....I saw Mum or my sister-in-law doing it. No measuring cup or anything you know. Mix it by hand, hand measure. Or sometime I'd use a cup. It turns out just as good. So I don't think I had trouble with learning Pauline to cook. I think when you're interesting enough you pick it up yourself. Yes, that's how I feel. [3:12]

Yura (Aboriginal) ${ }^{13}$ and Udnyu ways were combined in the family's lifestyle, though the older ways seemed always to dominate. Discipline of children was traditionally the responsibility of the maternal uncle, the mother's brother, but Pearl's mother took authority too, and used it, though her father rarely did. 'He was a wee bit softie,' she recalls.

You've been, you know, naughty with your swear or something like that, you know. Wouldn't do anything for your mother or something like that, the uncle's always the one that disciplined the children. Even girls, too....But they had authority. Anytime you couldn't argue with your parent if they around and you'll get a clip under the earhole. You know the uncle's the one that had control. [3:3]

Pearl remembers her parents with affection, as much for their relationship with each other as for their relationship with her.

I had beautiful parents....I never see a couple like that nowadays. Yes, they was really good mother and father.

GW: They were close?

Yes, they were close, doing everything. I tell everybody this. What they want to do, they both do it. Yes, when all working out, cleaning up, getting water, they'd both do it. [2:6]

...other parents...used to have arguments, my Mum and Dad never used to have them. They could have argument when I'm not there, but as far as I can remember they never fought against each other while we were around....But that's why I always says, my parents never ever had an argument. Yes, well, that's why I think I had good parents, yes. [2:24-25]

13. Yura is the Adnyamathanha word for an Adnyamathanha person but also is used sometimes more generally for any Aboriginal person. I use the terms Yura and Udnyu exclusively in this section of the paper because Pauline, in particular, prefers them to 'white' and 'Aboriginal.' In the remainder of the paper all four terms are used. 
When Pearl was about seven years old, missionaries came to Ram Paddock Gate where a large group of Adnyamathanha were camped. Pearl attended their school-but only when it fitted in with the needs of the family.

We had a bit of schooling, but I never had that much education because missionaries used to have us in school about a week-it might be fortnight. Then we'd be off school for, oh, couple of months perhaps, and I only went to grade 2. [1:21]

The missionaries introduced more than just formal learning. Udnyu games like rounders and cricket were also taught. Pearl also remembers the fun of skipping and playing Camel and Duckstone but no specifically Yura games. Together, the traditional activities and the introduced Udnyu games filled Pearl's life. She remembers her childhood as happy, despite the hard times of the depression.

I reckon it was very good. [pause] We never find it boring, not like nowadays children say, 'Oh, I'm bored here,' but we never used to. [2:24]

The Christianity that the missionaries introduced was not to have a significant effect on Pearl's life until much later but her schooling, or lack of it, began to affect her life choices in early adulthood. Soon after her first child was born, Pearl and her husband John moved to Martin's Well Station where he became head stockman. There were no other Yuras on the property so Pearl did not have the support of extended family in everyday living or in raising her children that she had experienced as a child. In most respects this did not seem to cause problems except when it came to formal schooling. Because of the isolation the children had to do their lessons through correspondence and School of the Air. And Pearl, of course, had to help them.

I wish I had more education than I had now....Yes. I mean teaching them correspondence might have learned me a little bit, you know. But it was too hard. And the worst trouble was....Because sometime they used to sneak out on me, you know. [1:29]

While only the eldest two children were getting their schooling in this manner, Pearl managed, but as more came along and Ivan, the eldest, moved into higher grades, the task became too much. Pearl believed that a good standard of education would be important for her children's futures and the only way to achieve this was to move to where they could attend a regular school. Ivan, Pauline, and Clive, the three surviving children, all completed Year 10 at Hawker Area School. 
I felt that I wanted my kids to know more than I did. Because I just could read and write, and the bit that I knew-and I have my three on correspondence. So it was getting hard when my fifth child was on, coming. And that's how I came in here, moved in here. For Ivan and Pauline to get well education. And this youngest one now, Clive, he went right through, you know, from Grade 1 upward. To three years high school he done. [3:9]

Pearl has seen many changes in her lifetime and in recalling earlier days she is aware that she now sees some things differently from when she was younger. Her reconciliation of Christianity and traditional dreaming is one example. What does not seem to have changed is her desire to pass on to her children their traditional culture as well as what she sees as good in Udnyu culture. From the time that her children were born she was concerned that they would have the benefits of both. This included physical care as well as the educational concern that we have already seen.

I had a really concern for my children to have the best. You know, I didn't want them to go hungry or anything you know. They'd go to bed without a feed, which sort of annoyed me. I used to always have something ready for them in case during the night they'll wake up and getting hungry. [3:10]

The main difference that she sees between the way she grew up and the way children grow up today is in the lack of time to learn and absorb traditional ways. The demands and speed of Udnyu culture serve to push traditional practices and therefore traditional culture into the background, where, she fears, they might be lost.

Well it might sound stupid I suppose. You know, they don't take much time in doing things, sitting down. And what I'd like to sit down and do with them-you know, give them the story and for them to write it down for me-but they can't seem to do that for me you see. 'Oh, tomorrow we might do it.' They'll you know, keep putting it off. And I keep telling them that tomorrow might be too late.

TR: All of those stories and all that information you got as a child yourself from your parents and the elders, sort of all the time I guess, because it was part of your life. Is that right?

That's right, yes. [ 3:12,13] 


\section{Pauline}

Pauline was born in Hawker, in very different circumstances to those of her mother. She was the middle child of the five children and the only girl. The year was 1954 and her life, and that of her siblings, was markedly different from the start to that of Pearl's. She did not grow up in the company of extended family in a traditional community. Pearl's father, John, worked permanently at Martin's Well and so visits with family and the wider Adnyamathanha community were short and sporadic. Nevertheless, Pauline's sense of family is very strong and she regrets that even today she does not always immediately know or recognize many of her cousins and nieces and nephews though she knows who they are and where they live.

The thing I used to find, was a lot of my other cousins that I didn't really get to see until I sort of actually moved in here....I mean even now, because I've lived up in Hawker, I mean, I never saw my cousins and I didn't see their kids. I mean they'd know me but I didn't know them and I used to find that very frustrating. [ 2:20]

However, one traditional aspect of Adnyamathanha life remained strong and was to have a profound influence on Pauline's life-the tradition of learning through practical experience. Amongst Pauline's earliest memories are accompanying and helping her father as he went about his work. The helping, as in traditional society, led naturally to learning.

When we was living at Martin's Well we was actually doing a lot of....Actually working with-you know, with Dad, I mean, you know, as kids....even before I was sort of going to school. It was still sort of like real life experience stuff with him rather than sort of doing school work as well, you know....we used to go fixing fences, I mean, and doing shooting. [2:2]

Because her father worked away from the house, she was away from her mother more than may have been the case in traditional society, and while, as we have seen, Pearl passed on to Pauline her own housekeeping skills, particularly cooking, Pauline seemed always to prefer the outdoor activities with her father. This was no doubt in part because she had two brothers. But also she remembers her father as not making any distinction between what she and her brothers could do and the level of skill they could attain. She always enjoyed competing with her brothers and had no trouble doing so successfully.

There was more pressure put on me because I was a girl, from my Mum, and with my Dad it was he saw me no different to the boys. It was sort of, you know, if he knew that, I mean, when he was doing anything-I 
mean, whether it was gutting roos or fencing or fixing the wingle or whatever-if I could help him, I mean, I'd help him. He wouldn't sort of say, 'No you can't do that because you're a girl.' I mean, if he wanted to have a grease monkey for doing the engine on the car, I mean, I was always there by his side....I think it was just old-fashioned sort of belief. I mean girls can't do things as well as boys, and I don't believe that, you know. I often used to grow up thinking-and even my Dad used to always say - well, you know, 'If you can't do it, at least have a go at it,' you know, no matter what it was. And you don't have to be a boy to go out riding motorbikes. I mean, I sort of used to live on motorbikes, stuff like that. But more mothers seem to think, you know, girls should be staying home doing this and doing girlie things. But I guess because I grew up with all boys in the family, too, I mean, I had no choice to compete....Even now I can see all those years paid off. I can sort of skin a roo better than my eldest brother, and he knows it too. (laughs) [2:14-16]

Helping her father was not all 'work' and would have allowed for many of the 'play' activities enjoyed traditionally by Adnyamathanha children-in the sense of practising and perfecting skills and the general social interaction and relaxation that interspersed traditional life.

We'd go out till two to three in the morning doing that sort of stuff [shooting roos]. Then even the middle of winter when it was really cold. I used to remember sort of sleeping with roos, you know, when he used to gut them. Because they were still nice and warm until he got the last one and there wasn't any.... Then he used to decide to, you know, wake up and have a warm by the fire, then we'd go off and, you know, shoot a few more. [2:2]

She and her brothers had some Udnyu toys. She remembers trucks and motorbikes but no dolls-she wasn't interested in them. Mostly games were played without toys, re-enacting daily activities.

I never really had much toys. I mean, I wasn't into dolls or anything like that. I mean, if I did have a toy it was sort of trucks and motorbikes. But, you know, no sort of really special....I didn't have a toybox or anything. Like I said, it was either out sort of digging wells with channels and stuff like that, you know. [2:3]

She also remembers playing marbles with quandong seeds and chasies [tag] with the friends and cousins she would meet at the Carrieton Rodeo.

But while many aspects of Adnyamathanha tradition continued in Pauline's life, Udnyu influence began much more strongly and at an earlier age than it had for her mother. In the absence of a maternal uncle, for instance, discipline became 
the daily responsibility of her parents. Pauline remembers her mother as the chief disciplinary force.

It was always Mum that did the smacking and it was always Mum that did the bossing around and stuff, because Dad wasn't sort of at home most of the day. I mean, you go out sort of mustering and stuff and come home late. So, you know, the time we sort of had any time together was, you know, camping and stuff on weekends, and nine out of ten he used to stick up for us anyway. You know, you'd do something wrong and.... [1:14]

At about age five she joined her older brothers in their correspondence and School of the Air lessons. Pearl's attitude to schooling was quite clear to her children. It was she after all who had to supervise their lessons and give what assistance she could to three lively children who generally would rather be outside playing or helping their father.

We used to sort of skip lessons and be quite happy to go out doing things with Dad. Cleaning troughs and whatever, you know-making the stuff he was doing around on the property, to Mum's disgust. I mean she....Because, you know, there was times where we'd sort of tell Dad that we'd finished our lessons, which we didn't, and Mum'd be looking for us and we'd gone with him, you know. [2:4]

John's attitude to schooling was different. He clearly valued the practical learning that came, in the traditional way, from being actively involved in daily life. But that is not to say he placed no value on formal Udnyu schooling. The decision to move to Hawker for the sake of the children's schooling was a mutual one and meant a change of work for him. The fact that he taught himself to read and write indicates that he could see the necessity, or at least the desirability, of a basic education.

I think he wanted us to actually, you know, go to school and stuff. But you know, like I say, I mean he never went to school himself. [1:5]

Family life and family celebrations were important to the McKenzies, but again, the experience of the children was far removed from that of their parents. No traditional ceremonies remained. Those that were celebrated were Udnyu. Pauline remembers birthdays as being important for the children although the celebrations were simple. A cake and a few presents made them special.

We used to have like, just for birthdays, we just sort of....I mean, no matter where we were, I mean, I could always remember we'd still have a birthday cake, you know-and even before we sort of moved into Hawker....we got presents. I mean it wasn't sort of anything fancy, but 
I would be really-just sort of appreciate just even a packet of lollies or a block of chocolate, you know. I don't think I....You know, not like kids now. I mean they get all sorts, you know. [2:6]

This was something that was for the children only, though, for John and Pearl did not know their exact birth-dates and so did not celebrate them. Christmas was a special family time, too.

I can remember Christmas-but not really Easter. We didn't have Easter eggs or anything like that. But certainly Christmas, and the thing that I could remember about Christmas is the fruits. I mean, it was the only time of the year that we could, you know, get things like apricots and cherries.... [2:6]

The Carrieton rodeo was important, too, because it was a time to meet up with friends and relations.

And that was actually not actually just to see the rodeo. It was just a time where everyone used to actually meet too, you know, all the other people—relatives and stuff. [2:5]

The School of the Air Christmas party at Port Augusta each year was also a special event, though as with all large gatherings, it was something of a trial to Pauline. She was a shy child and mixing with large groups of strangers was not easy.

As a child, I mean, I was very shy, too, and that made a lot of....I mean, not sort of difficult but, you know sometimes you just....You know, with seeing so many people around you didn't feel comfortable, sort of, actually. $[2: 7,8]$

There was also the added embarrassment of being aware that she was a Yura in a crowd of Udnyus. She remembers being very uncomfortable when her mother would speak to her in Adnyamathanha when Udnyus were around even though the family normally used both languages in daily conversation.

I guess sometime I used to be a bit embarrassed. Like when Mum used to be talking to me in our language, you know, like if we were down there at School of the Air, or maybe down, you know, in the main street of Port Augusta. She'd be, you know, trying to talk to us in Adnyamathanha and we didn't want to listen. We'd sort of say, you know, 'Not here. Wait till we're out there,' you know. [2:8]

Pauline quite liked some aspects of school at Hawker. 
Oh, there were certain things I liked about school I guess. I mean, you know, sort of actually sort of mixing with other kids. I mean I enjoyed that. [2:9]

However, she was aware of a problem as a child that she could not at that stage put into words. Even now it is not easy for her to express but it concerned the absolute lack of any acknowledgment of Yura culture in her schooling combined with condescension on the part of some Udnyus.

I just felt that there were times that they didn't actually want us to be sharing, you know, the stuff that we knew and make us feel proud to be what we were, rather than sort of you know-I mean, the stuff that the kids are doing in school now, I wished I did it when I was at school. I mean things like Aboriginal Studies, you know, and it's really making a hell of a lot of difference with our kids at school now. But I was really embarrassed, you know, at times, when they'd be sort of looking at....We might have did a history class and Captain Cook or something, and they often used to say-oh, you know, talk about these Aboriginal people, they were savages and stuff like that. And I used to feel really terrible about that, you know. [2:11]

This may explain her interest and involvement in the education of both Yura and Udnyu children today. As an Aboriginal Education Worker at Hawker Area School, Pauline feels strongly that Udnyu children should learn something of Yura culture, too. She sees this as important for actually retaining Adnyamathanha culture as well as in passing it on. But often there is no time for sitting and listening that is so important. Udnyu culture intrudes everywhere.

In the past the kids used to always sit down and listen to the stories, but now we've got too much interference. I mean, you know, we've got things like video and TV and stuff, and you can't really sort of sit down and talk to somebody, or tell stories if they're watching the video. I mean, you'll get told off, get out of the room. (laughs) $[1: 9,10]$...I think they're very much into white culture. [1:12]

However, she has an increasing conviction that the simple inclusion of Aboriginal Studies in the normal school curriculum is not the answer. The traditional Yura way of learning by doing is essential, too.

I guess a lot of it was actually people seeing, and that was very important, you know. If they were able to sort of see what, you know, and I think that's a lot of things that are missing now, you know with kids. They don't actually sort of get the experience—real life experience stuff like that, you know. [1:17] 
I know I shouldn't say it - but you can't learn everything just sitting in classrooms, you know. I think you're better off out and about and actually doing and seeing things. And that's why I always, even sort of with Aboriginal Studies, you know, for kids now, I mean, to get any meaning out of anything it's best if they actually go and visit some sites or.... [1:12]

Pauline's own lifestyle is probably more Udnyu than Yura in many respects, at least in its everyday visible forms. She has clear aspirations for her own daughters.

I've been really putting a lot of emphasis on the need to stay at school and finish their education, you know. Because without....Even now, without your Year 12 Certificate or whatever, it's really hard out there to get a job. [2:17]

But she realizes that she has the advantage of being brought up in a family in which Yura ways were still strong and in which there was a clear link with the traditional culture and the preceding generations. It is that sort of link that she believes is essential that her generation preserve for the future.

\section{Charlene}

Charlene is the oldest of Pauline's three daughters. She was born in the Hawker hospital on September 9, 1972. Her next sister, Carey, is two years younger and the youngest is Carmella, born when Charlene was nine. Charlene has lived in Hawker all her life so far, though she does not anticipate remaining there forever. She has just become engaged to a young Adnyamathanha man who also grew up in Hawker. At this stage she is in no hurry to get married, which pleases Pauline but concerns Pearl a little. She has a desire to be financially secure, especially before she has any children, and would prefer to live 'out bush.' She works as an Information Officer at Wilpena Pound.

Outwardly her life has had the structure and format of a Udnyu, with formal schooling playing a major role. Indeed, her formal education has been more comprehensive than that of many Udnyus. She began by attending the local kindergarten, where Pauline was a teacher, then went right through to Year 11 at Hawker High School, doing the last year by correspondence. Initially she thought she would like to be a lawyer but changed her mind. She then came down to Adelaide to do a business course at an Adelaide TAFE with the intention of establishing, with a group of her relatives, an Adnyamathanha Cultural Centre in Hawker. 
See, we want to have a permanent cultural display in the centre and it'll be something like artifacts and food and stuff-like bush foods and bush medicines and stuff like that in the centre-and like create more employment for Adnyamathanha people around Hawker and it's for the general public. [1:2]

This was a project that Pearl and John, her grandparents, had long wanted to get off the ground but did not quite know how to go about. Charlene sees the approach that she and her uncles and cousins took as being a practical and rational one and, moreover, one that is likely to be successful. The fact that it was something that both her grandparents wanted is clearly important to her. It will serve to preserve and pass on the Adnyamathanha culture that they passed on to her and this is important to her both as a sign of love and respect for them as well as for the benefit of the children she may one day have.

I guess like, because for the past twenty years both my grandparents, like Pearl and John, and my great-grandmother, May Wilton, they worked with the linguist, John McEntee, on our language, recording our language,....and I guess it's their determination and dedication that sort of gives me the get up and go, makes me sit up and think, you know, 'Well, if they can do it to preserve our culture, why can't I do something like that?' $[1: 3,4]$

Despite the fact that she grew up in the town her earliest memories are of going bush with her grandfather and helping him with jobs. She found him a lot of fun and learned all sorts of things Yura and Udnyu from him, as had her mother before her. She remembers Pearl and Pauline staying back at camp doing the cooking and other chores but she was not interested in these and preferred to be with Poppa instead. Childhood was a happy time for her.

I think when I was about a month old they (Nanna and Poppa) first took me out camping and then ever since then I just went out with them all the time. And like my grandfather, John McKenzie, he was my idol and my hero. Like he taught me how to shoot and how to prepare bush foods, and different types of bush tucker and stuff, and I just really enjoyed the bush. [2:3]

If we didn't go out camping then Poppa and I'd go out shooting during the week. Or when I was younger I used to go out spotlighting with him.... When we used to get, like, the three month break over Christmas we used to be out on the station with Pop. Just go out there. [1:3]

He taught her to shoot, as he had Pauline, and she was about ten years old when she shot her first kangaroo. Prior to this she watched, in the traditional manner. When she was at home she remembers playing 'boys' games-she always felt happier doing 'boys' things. Like her mother, she was a tomboy and 
this was not discouraged by Poppa. In fact, although her siblings were girls, she recalls mostly playing with boys throughout her childhood. She didn't have many toys at all that she remembers, though Pauline recalls a large orange teddy when she was a toddler. Mostly it was cars and active outdoor pursuits like swimming, horse and motorbike riding, and the regular bush camping with Poppa. She sees herself as being much like her mother in terms of her love of the bush and preference for 'boys' pursuits. But she sees herself as having a greater freedom than her mother in that she could choose whether she would wear girls' or boys' clothing and play girls' or boys' games. She sees Pauline as not having been given this choice by Pearl.

Charlene sees herself as bringing up any children that she may have in much the same way as she was, although she is adamant that any daughter of hers can grow her hair long whenever she likes and will not have to wait until she is old enough to look after it herself as she did. Like her mother and grandmother, Charlene has a strong sense of the importance of passing down knowledge and culture from generation to generation. She sees herself as having both Yura and Udnyu culture to hand on but the Yura is of particular importance because its very survival is under threat. She feels an obligation to pass on all that Poppa taught her to her own children in the future. 'He taught me for a reason,' she says. On the other hand she realizes that there were many things that he could not tell her because they were 'men's things' so she sees her major obligation as passing on her knowledge through the female line. 'I'd have to have a daughter.'

Special family times stand out in her memory. The children's birthdays were always celebrated. Pauline would make a rocket cake-two layers, iced and decorated with smarties or such and with a single large candle in the middle. There were presents; Poppa always gave her bags of various sorts, Pauline also gave practical items like clothes rather than toys. These celebrations were for all the family and relations would come over for a barbecue. Christmas was another time that the family spent together. Aunts, uncles, and cousins would come up from Port Augusta. Each nuclear group would have separate lunches, then all get together for tea in the evening. Easter was not celebrated at home. Charlene remembers Eastertime at kindergarten because she got prickles in her feet searching for eggs but not any celebration at home other than eating hot cross buns and each girl having a single Easter egg.

Charlene enjoyed school though it was no competition for bush life with Poppa.

Yes, I did like school. I wouldn't say that I hated it because, like, I enjoyed learning. But, I mean, if I had a choice between school and staying out bush with my grandfather, I know where I'd be and it wouldn't be in school. (laughs) [2:3]

She had no difficulty with the work which is perhaps why she was not aware of how important Pauline felt it was that she get a good education. 
No, well, she wasn't really....I don't think-looking back now,-I don't think she was really interested in our schoolwork. Because, like, the only time I can remember her ever, like....She didn't really encourage us. She'd just tell us off whenever we used to get behind or whatever and give us a bit of a push. But I guess, I don't know. No, I can't remember.... [2:4]

Charlene had an independent spirit and knew what she wanted in a way that did not always sit well with her mother's ideas and desires. For instance, Charlene wanted to do her last years of schooling in a regular classroom situation rather than working by correspondence but Pauline was unwilling to let her move so far from home.

At the end of Year 10, I wanted to go away and go to a school in Adelaide or Port Augusta because Year 11 and 12 is not good at Hawker. Like, it's all by correspondence and I think it puts a lot more pressure on you. You just fell too far behind when you have to do it by correspondence. And she didn't want to send me away and I wanted to go away so that I could do better....But you know, she didn't want to send me away and I wanted to go. And I thought, 'Well, I'll just leave,' so I left school, but I don't regret it-I don't regret leaving. [2:4]

Likewise, Pauline was not happy about her plans for a student exchange in France.

Like when I was in Year 10, I applied for an exchange to go to France, like, because I was studying French at the time, and I got accepted but Mum wouldn't let me go. You know, 'What if the plane crashed?' or 'What if you got hijacked?' or 'Oh, my God,' and she just wouldn't let me go. [2:5]

Although Charlene's experience of school is recent she regrets that there was little Yura content in the courses.

There was this one time when a few of us wanted to learn, like the Adnyamathanha language, and we were currently taking French and German lessons and, you know, that's when I first started to get....About two years after I started taking French, I thought, 'Well, why should I speak another language when I can't speak my own?' So a few of the other Aboriginal students in the school and myself we got together and said, 'Well, we want to be taught our own language.' And we approached several of the teachers and the Principal, but they just wouldn't be in it. [1:12] 
Apart from Adnyamathanha language, Charlene would like to see bush lore and skills and dreaming stories taught in the schools.

I'd probably go in and teach, like, I'm really interested in Aboriginal plants, different sorts of plants, like medicines and stuff, and bush tucker. I guess that's because I spent time with my grandfather and like he showed me, you know, different plants and stuff that were used for....I guess Mum's influenced me, too, because she's pretty well interested in that...I guess plants. [pause] The dreaming stories I reckon. Teach them how the dreaming stories connect us with the land and that. [1:18]

To a much greater degree than her grandmother and more, too, than her mother, Charlene has a sense of her own individuality and the importance of shaping her own life. This is no doubt a personal characteristic to some extent but the changing combinations, over the three generations, of Yura and Udnyu culture, life, and learning have also have had an effect.

All three women value their traditional heritage, but their emphasis and priorities are slightly different. For Pearl the important thing is to simply make sure that the knowledge that she and other elders have is passed on to younger people before it is irretrievably lost. For Pauline the priority is the collection of the knowledge. Charlene wants to ensure that what is collected will be safeguarded for the future in a way that will make its survival less dependent on the passage from one individual to another. After that she has things she wants to do for herself.

So I guess I want to stay here long enough just to see that [the cultural centre] set up and up and running, and then hand it down to one of my little sisters or some of the younger ones in Hawker that want to stay in Hawker, or some of the older ones that, you know, want to stay - that have decided they want to stay here and they want to run it. And once I know that they will run it effectively and it won't fall through or whatever, then I'll leave. [1:22]

\section{Methodological Problems}

There are a number of methodological problems and problematics concerning these stories, the data with which I, as a historian, have to work. First, how do I use them and, second, what significance do they have? For one thing is increasingly clear to me: if I use them in traditional western academic ways the result will not be considered legitimate by either Aboriginal peoples or by 
academics. So let me explore briefly some of the cultural and methodological problems.

\title{
The 'Problems' of Aboriginality
}

\begin{abstract}
Margaret Mead has said,
It's a good thing to think about the child as long as you remember that the child doesn't exist. Only children exist. Every time we lump them together we lose something...It is not just a matter of the enormous differences between individuals. Every child is in a different state of being or becoming. ${ }^{14}$
\end{abstract}

I believe that this might be said with as much truth about any group of people: children or adults, white or Aboriginal, or of any other cultural background for that matter. Each individual is unique, each is variable. While the group may with truth be said to be more than the collection of its constituent parts, the process of collection or amalgamation into a whole can render invisible factors to do with individuals that have great significance. The most obvious example of this is the tendency of white Australians, and perhaps at times some Aboriginal Australians as well, to lump all Aboriginal people and their culture together as one. This is a serious mistake. There are many Aboriginal peoples and Aboriginal cultures in Australia. They are all connected, some very closely, others less so, but they are not one homogeneous people, either in terms of their traditional cultures or in terms of their contemporary experience, desires, or aspirations.

Let me give an example of one area in which the diversity of attitude and approach of Aboriginal peoples is particularly marked. Eleanor Bourke of the School of Aboriginal Studies, University of South Australia, recently called for white academics to back off for a period and allow Aboriginal people to write their own histories. ${ }^{15}$ At the other end of the spectrum the Warramirri people of Arnhem land have allowed a white associate to assist them with publication of aspects of their culture that until recently have been secret, in a move designed to assist inter-cultural understanding between themselves and mainstream white culture. ${ }^{16}$ There are no doubt all sorts of positions in between the two extremes.

14. M. Mead, remarks at the Symposium of 'Children, Nature and the Urban Environment,' Washington, March 1975, quoted in C. Ward, The Child in the City (New York: Pantheon Books, 1978), Foreword.

15. Education Department Staff/Student Seminar, University of Adelaide, 18 June 1993.

16. J. Cawte, The Universe of the Warramirri: Art, Medicine and Religion in Arnhem 
The people with whom I have been working identify themselves as Adnyamathanha; their loyalties and aspirations are towards the Adnyamathanha people and culture rather than to the broad concept 'Aboriginal.' This is not to say that they have no interest in other Aboriginal peoples. There is a strong feeling of kinship and sympathy but there is nevertheless a sense of separateness as well. My own observation is that there is a far stronger sense of solidarity, stemming from the present, arising from a sense of shared difficulties and disadvantages in coping with the effects of white society than there is in relation to traditional cultural ties. This may or may not be the case with other Aboriginal groups or individuals.

How does the fact of their Aboriginality affect these women and affect the ways they and I together record and publish their stories? There are several ways. The first is in relation to ownership of the data that they are allowing and assisting me to collect. White academic tradition has tended to hold that once individuals have agreed to give information, whether it be factual data or more personal information, that information becomes the intellectual property of the researcher who is free, indeed must be free, to make whatever analysis and draw whatever conclusions he or she thinks appropriate. This is not the attitude of the Adnyamathanha with whom I have been working. Their stories, whether Dreamtime or personal, are theirs permanently as far as they are concerned. They may choose to share them with others but they do not give up the ownership. Therefore they have a lively interest in the uses to which their stories are put and the ways in which they might be presented to others. As a condition of sharing the information they wish to be involved in the preparation of the final product and to feel comfortable about its form, content, and nature. It is their individual and collective self that is being put on public view.

Second, there is a political facet to their desire to maintain control of their selves and their identities. Ever since white settlement, they, like other Aboriginal people, have been denied the right to control and determine their lives. In the current political and social climate they see possibilities for redressing this situation and are determined therefore to use whatever methods seem to offer the likelihood of success. Education of the white community is an approach that particularly appeals to these three women but they wish to ensure that they have control of the 'curriculum.' Recently, after a particularly long interview session, I asked Pauline whether she got sick of being asked constantly by Udnyus about her culture and her experience. Her answer was that yes, she did get sick of it but it was worthwhile if it served to advance Adnyamathanha goals of regaining their cultural inheritance and acquiring greater power and recognition within Australian society.

Third, there is the difficulty of what we might call inter-cultural incompatibility. Too often a dominant group automatically assumes that a second, less

Land (Sydney: University of New South Wales Press, 1993). 
powerful group can be understood, analyzed, explained, using the tools, parameters, constructs, etc. of the dominant group. Different cultures frequently have very different ways of looking at things and if these differences are not recognized all kinds of confusions can arise. The research project of which my work is an offshoot began with the goal of looking at indigenous art and quite an amount of work had gone forward before it became apparent that there was a problem with this in the Adnyamathanha context. Informants were quite able to discuss, in English, art and artifacts relating to their culture. It was only when interviewers began to ask questions about the relationship of the former to other aspects of Adnyamathanha culture, questions specifically tied to language and its usage, that discussions came to an abrupt standstill. The Adnyamathanha have no words for art and the aesthetic concepts which are tied to it in western culture. We were using a construct that had no existence outside our own culture. It is hard to keep a look-out for problems that may be invisible in this way but if the results are to be valid, the attempt must be made. Often the clues will come from the people themselves rather than from accepted academic practice or knowledge.

Finally, one must ask, given the problematics involved, will the final results be worthwhile? It could be argued that in allowing so much input from the sources, the interviewees themselves, I and other researchers on the project are abdicating both control and responsibility for the outcomes which could instead be directed by inappropriate or hidden agendas. I do not believe this to be the case. As an academic I have always been in the habit of discussing my work with colleagues, looking for constructive criticisms and suggestions. Without such input my work would be much the poorer. The people I have interviewed are not academics but in terms of their culture and their experience they are the experts. Therefore it seems both ill-mannered and stupid to take only data from them and to fail to ask for their opinions, analysis, or explanation of the significance of that data. By working together we have produced far better results than either could have achieved alone.

\section{Reliability of the Data}

How much faith can one place in the reliability of memory of past times, past feelings, beliefs, and perceptions, particularly if one accepts that each individual remakes his or her past to some extent with each remembering ? $^{17}$ The answer, I

17. M. Peters, 'Children's Culture and the State: South Australia 1890s-1930s' (Ph.D diss., University of Adelaide, 1993), 29; N. Sutherland, 'When You Listen to the Winds of Childhood, How Much Can You Believe?' Curriculum Inquiry 22, 3 (1992): 235-56. 
think, depends on who is being interviewed, what sort of information is sought, and what you want to do with it.

These sorts of questions have always been a problem for academic historians. Oral history has enjoyed a small but legitimate niche in Academe, but still it is often ignored by many academic historians or discounted along with 'local' or 'amateur' histories as being not sufficiently objective or analytic. ${ }^{18}$ The academic tradition, in history at least, has always set great store by objectivity. The subjective may add colour but corroborating evidence has always been demanded before any 'serious' analysis can be made. ${ }^{99}$ Besides this, traditional academic authors have deliberately placed themselves between their subjects and the data in the interests of further ensuring the objectivity of the final product.

This is as true of 'personal' evidence gathered in a more structured manner, say by written survey or memoir. Even serious historians who are writing for a non-academic audience are careful to use personal evidence that can be corroborated by other independent data or in such ways as to indicate that veracity is assured, or at least implied, by the large number of interviewees giving similar responses. I am thinking particularly of Journeyings, Janet McCalman's recently released biography of the Melbourne middle class. ${ }^{20}$ I am thinking also of Brian Dickie's review of this book and his criticism of the 'self-conscious self-satisfaction' of this group of people that comes through in their evidence without any apparent conscious intention by McCalman. ${ }^{21}$ To my mind this is one of the strengths of the book and one of the best justifications for using 'biased' personal views.

Having made these points, however, I must also say that I believe there is an important difference between the nature of the data gathered from white respondents and the data that is obtained from Aboriginal people. In the former situation there is not the cultural gap between white interviewer and subject that exists in the latter. In the former, even where differences of attitude, values, and experience may exist due to class, religious, or other differences, there is still a vast pool of cultural commonality. In the latter case, while commonalities may exist they nevertheless stem from a profoundly different base.

The two differences that have been most obvious to me in my interviews with these three women and with other Adnyamathanha is the influence of the oral nature of their culture and the strength of the collective or group ethos over

18. See P. Thompson, The Voice of the Past: Oral History (London: Oxford University Press, 1978), chaps. 2 and 3 for a useful discussion of the possibilities of oral history.

19. For instance see Oral History Handbook (Oral History Association of Australia [South Australian Branch], 2nd ed., 1992), 2; D. Reimer, ed., Voices: A Guide to Oral History (Provincial Archives of British Columbia, 1988), 2, 4.

20. J. McCalman, Journeyings: The Biography of a Middle-Class Generation 19201990 (Melbourne: Melbourne University Press, 1993).

21. Brian Dickie, Review of J. McCalman, Journeyings, in The Advertiser [Adelaide] Saturday Magazine, 23 Oct. 1993. 
oral nature of their culture and the strength of the collective or group ethos over that of the individual. The resulting data, therefore, differs significantly from evidence that might be gathered from a similar study in modern urban white society. The Adnyamathanha, like other Aboriginal peoples, have a long tradition of passing on their culture orally. Under such circumstances, changes cannot be allowed to be introduced at the whim of an individual or the entire cultural base is put at risk. This tradition, though influenced by 150 years of white contact, is still strong amongst the Adnyamathanha and their narratives show a far greater consistency than one would expect to find with white respondents. ${ }^{22}$ Unasked, these three women independently and consistently corroborate each other's narratives, not only in matters of fact but in areas related to values and attitudes as well. They report each other's experiences, whether factual or attitudinal, as they have been told them or have observed them.

They also tend to report from the point of view of the group rather than from a personal point of view though this tendency is diluted to some extent with each of the three generations. To get Pearl to talk about her own personal experience, particularly in her childhood, is difficult for she still has problems separating her own experience as an individual from that of the group with and for whom she lived. This tendency has ramifications that are still important in the present, for despite the development and growth of individual and personal opinions, the Adnyamathanha still have collective goals and aspirations and the telling of tales, whether they be the traditional Dreaming stories or personal individual 'stories,' is seen as a way of pursuing these collective goals.

Finally, I am also a part of these stories, by necessity rather than choice. I appear at several levels. First, I influenced their remembering by asking them to talk about themselves. Then, in order to transfer their lives from tapes to paper I had to act as editor, both of the content of their narratives and of the ways in which they were expressed. I could not simply reproduce their narratives in toto so the result has to be, to some extent at least, my interpretation of their words and their meanings. I have tried to do this without imposing myself on them too much but it is impossible not to enter the text in some way. I have tried to neutralize or overcome the intrusion of my presence by using their own words as

22. Tony Rogers has expanded on the importance of the accuracy of transmission of traditional Aboriginal cultures elsewhere. See T. Rogers, 'Art and Aboriginal Cultures,' Australian Journal of Art Education 17, 2 (1994): 12-20; see also P. Thompson, 'Memory and Multiculturalism,' VIII International Oral History Conference, Siena-Lucca, 25-28 Feb. 1993, p. 1145, for a brief discussion of similar clarity and accuracy in family memory in a very different culture. He uses an example from the western Scottish Isles when immigrants left for the United States in the early nineteenth century. Their descendants today tell the story of their departure as vividly as if they had observed it because the stories have been passed down so accurately. This is a western, not an indigenous, culture, but its oral tradition is obviously still strong. 
much as possible, for the telling, in oral tradition, is as significant as the tale. ${ }^{23}$ But still, much is lost in the transcription from tape to paper. The sound of the women's voices, the ways in which they speak, all add extra meaning to the words. All three women have had a chance to read what I have written and to make comments and changes where they wished. The result is something that the four of us have agreed upon. But it is certainly not traditional history, and none of us are completely happy with it as it stands. The challenge is to find ways of using the data that are acceptable and useful to both Adnyamathanha and Academe.

\section{Extrapolating from the Individual to the Group}

If we accept that the data, while qualitatively different from those usually employed by historians, are nevertheless valuable, in what ways can we use them? Can we make generalizations from the lives of three women from a single family to a larger group that is scattered geographically and whose members all have somewhat different individual experiences along with their commonalities? What use can we make of the remembered past of three individual women? Do their own perceptions of their lives have a role to play in assisting others, white and black, to understand and appreciate the broader history of their people? I believe they do but an academic justification is not easy to formulate. As long as we see each of these women as an individual member, rather than as a representative example, of her respective generation, we can, I believe, make illuminative connections from one generation to another and with the broader society.

This goes against the current of white academic tradition which has largely attempted to interpret and explain in reference to the whole group, whether that group encompasses an entire society and culture or a specific sub-group within it. There has been an accepted place for the examination of the individual but it is implicit in our understanding that this is a different kind of study. The individual is examined, generally within the disciplinary frameworks of biography or autobiography, precisely because he or she is different from the group. Unless there is some difference there is no justification for a focus on the individual. Recent post-modern scholarship, particularly under the influence of Foucault, has turned this kind of approach on its head, bringing the subjective to the forefront and rejecting the objective as misleading at best and useless at worst. This newer approach has all sorts of problems of its own which I do not want to address here. But it also seems to offer some alternative ways of dealing with

23. S. Muecke, Textual Spaces: Aboriginality and Cultural Studies (Sydney: University of New South Wales Press, 1992), 52, 53. 
both data and situations which in the past have not been addressed, in part, for want of ways to approach them.

What I have tried to do is to straddle the two academic traditions of analysis and interpretation of the group and of the individual. In this sense the product bears a resemblance to the group biography. And yet what I have done is not a group biography, at least I don't think so. For as I have said, the biography assumes its subject(s) stand out from the norm in some way, even if the norm is not overtly identified. I have no concern at this time with norms or generalizations. These narratives are not intended to say anything about children as a group, about women as a group, about the Adnyamathanha as a group, nor even about familial and inter-generational relationships in general. They are simply aspects of the lives of three generations of Adnyamathanha women as they see themselves, each other, and the world they live in.

\section{Educational Implications}

What is the significance of the educational experience of these three women? What, if anything, can it tell us about the ways that education and/or schooling can affect the lives of individuals and groups? Or alternatively, what can it tell us about the ways in which individuals and/or groups can use education/schooling to mould or direct their lives or their children's lives? Perhaps more importantly, can we, and how can we, structure and theorize the analysis?

If we took each of the three women as broadly representative of her generation, and in some ways they are, we could draw parallels with the growth in the amount, type, and structure of education in white society since the development of mass public schooling in the second half of the nineteenth century. Also the temptation to generalize the similarities between Aboriginal and at least some aspects of working-class experience is strong: social control, resistance, cultural hegemony, and bio-politics are just some of the white academic concepts that spring to mind as possible theoretic structures for analysis and interpretation.

But there are two major differences at least that make this sort of approach problematic. First, the speed of growth in the educational experience is extremely rapid; only three generations from a traditional oral culture to post-secondary education. Many white working-class children do not yet complete secondary education, let alone aspire beyond it. But then neither do most aboriginal children, for as I said earlier, Pearl, Pauline, and Charlene are not representative examples of their generations despite the fact that some generalizations can be made from them as individuals to their people as a whole. Second, while one may argue that a working-class culture or cultures existed beside the dominant middle-class culture (or cultures?), both (or all) of the cultures grew from basically the same roots. This is not the case with Aboriginal and white Australian cultures. They are about as different as they could be in terms of conceptualizations, attitudes to life, and everyday practices. 
The experiences of migrant (voluntary or otherwise) groups, particularly those from non-European cultures, may make for a better comparison. Some studies of Afro-American experiences offer insights into the two-way process of assimilation and the ways in which a subjected culture may take what it wants or needs from a dominant culture while still maintaining some of its own traditions and culture; but further comparisons are not really tenable because of vast differences in the situations and time frames. ${ }^{24}$ Similarly, studies like Tim Stanley's of the Victoria, British Columbia, Chinese, who might be said to have more similarities in terms at least of time frames and determination to use white education systems, will still not serve, and for two basic reasons. ${ }^{25}$ One, Aboriginal peoples are not immigrants, it is they who were invaded, or less confrontationally, intruded upon. Two, existing studies that are acceptable to Academe, no matter how sympathetically done, are produced from the white perspective and within white theoretical structures and frameworks. My argument is that this will not suffice in the 1990s for studies of Australian Aboriginal or other indigenous peoples. But what to use instead I do not know. Perhaps a sophisticated theoretic structure is unnecessary, perhaps one will develop as more work is done in the area. In the meantime I think the important thing is that the people themselves retain access to and control of their histories in the same way as these three women demonstrate their continuing desire for access to and control of their own and their children's education. Moreover, their own voices must be recognizable in the written work that results.

A crucial factor in regard to education in these three personal life stories is the increase, with each generation, of the influence and importance of formal white schooling and the perception of each woman that the acquisition of such schooling is both necessary and desirable, either for her own satisfaction and ability to achieve desired goals, or for the future benefit and well-being of her children, or both. But equally important is the value placed on traditional knowledge and ways of learning. Pearl and her husband John left Nepabunna soon after their marriage and from then on lived in Udnyu ways rather than tribal ways. Their lives were dictated by the 'white' demands of work and they were removed physically from the large extended family groupings of traditional life. They nevertheless managed to pass on to Pauline and her brothers a large amount of traditional skills, knowledge, and culture-not sufficient to preserve the culture wholly, but certainly enough to give Pauline both the desire and ability to continue the process with her own daughter.

24. For instance, E. Genovese, Roll Jordan Roll: The World the Slaves Made (New York: Pantheon Books, 1974); T.L. Weber, Deep like the Rivers: Education in the Slave Community 1831-1865 (New York: W.W. Norton, 1978).

25. T. Stanley, 'White Supremacy, Chinese Schooling, and School Segregation in Victoria: The Case of the Chinese Students' Strike, 1922-23,' Historical Studies in Education/Revue d'histoire de l'éducation 2, 2 (Fall 1990): 287-306. 
The methods by which this process took place and the effects which resulted are relatively easy to uncover. What is more difficult to ascertain is the motivation. It is too easy to say that this family, or as Brock has claimed, the Adnyamathanha as a people, simply saw the advantages of the white lifestyle and white education and went ahead unproblematically to incorporate them into their own lives. To a large extent, though indirectly, white education and lifestyle were forced onto them. The first missionaries at Nepabunna appear to have been relatively sensitive to traditional culture and practices. Apart from their obvious aim of conversion to Christianity, they did not attempt to suppress the language, discontinue ceremonial life, or impose white schooling. In fact they offered only sporadic schooling sessions when other tasks permitted.

Elements of overt compulsion only intruded in the late 1950 s and 1960 s with a change of missionary personnel and the posting of Education Department teachers to the Nepabunna school. Force of circumstances seem to have been stronger. By this time too, it was necessary for the men and sometimes the women to work at whatever jobs the pastoral economy offered. Many were more than happy to do this for it did not sever their ties with their land and allowed for the continuation of some traditional activities. Pearl and her husband John saw this option as the best for themselves and for their children. Having chosen it, they proceeded to make the best use they could of the advantages that it offered them for the future.

Perhaps one of the more important characteristics that they seem to have passed on to their children and grandchildren is this ability to identify and pursue a course of action that fits with existing values and desires and/or adapt to some extent those values, desires, and practices to fit with what is attainable. This ability is no doubt a personal and inherent characteristic to some extent but it is also a learned ability, too. It is an example of learning or education in the very broadest sense of the words. Pearl's father, Henry Wilton, and John's father, Fred McKenzie, were the last two traditional leaders of the Adnyamathanha: the men who made a conscious decision in the late 1940 s to terminate the initiation ceremonies because the physical and cultural environments had altered to the extent that they could no longer be carried out in fully correct ways. This desire and ability to preserve tradition where possible but to accept change where necessary or desirable seems to have been learned and incorporated by each generation since.

A second vital factor in the trans-generational experience is the value placed on both the Udnyu and traditional methods of learning. This has not always or necessarily been a conscious valuing. Pearl wanted the best she could obtain in all respects for her children, both white education and traditional knowledge, and she simply went about obtaining them as best she could without much clear analysis of the situation. With hindsight and with the accumulated experience of her daughter and granddaughter in learning through both informal traditional ways and formal white methods, she is able to separate the two and assign value to both. 
Pauline has even stronger views arising from her own more extensive formal education and her experiences teaching in white schools and in residential cultural camps for overseas students and local Education Department teachers. Not only does she value both Yura and Udnyu knowledge and ways of learning but increasingly she sees the advantage and necessity of using both together so that both races can learn effectively together and share each other's knowledges. Charlene, too, although she has no experience of teaching, either children of her own or of other people, favours the combination of both cultures' knowledges and approaches to learning.

Over the course of three generations these women have been very successful in the ways they have approached, appropriated, and incorporated two very different cultures and two very different ways of learning. If nothing else, both white and Aboriginal societies can learn and benefit from their experience. There is, of course a major difficulty. Both cultures have developed ways of perpetuating themselves that, because they are deep and rich cultures, take whole lifetimes. White learning about white culture and how to live within it does not end just because formal schooling is completed, just as Adnyamathanha learning about Adnyamathanha culture and how to live within it did not end with initiation as a man or recognition as a woman. Learning to live well in either takes a lifetime. Finding time for both, as Pearl says, is difficult. But the combination of aspects of both is possible, as the lives of these three women demonstrate. 